\title{
EFFICIENCY EXAMINATION OF ANTIHYPERTENSIVE FIXED-DOSE COMBINATION IN PATIENTS PREVIOUSLY TREATED WITH ANTIHYPERTENSIVE MONOTHERAPY
}

\author{
Nemanja Nikolić ${ }^{1}$, Tomislav Kostić, ${ }^{4,6}$, Marija Marinković2 , Mladjan Golubović3 ${ }^{3,7}$, \\ Tamara Stojanović4, Milena Manojlovićs ${ }^{\text {, Igor Petković }}{ }^{8}$
}

\begin{abstract}
Arterial hypertension is the condition where the blood pressure is higher than $140 / 90$ $\mathrm{mm} \mathrm{Hg}$. Along with its complications, it is the leading factor for cardiovascular mortality. Arterial hypertension can be systolic, diastolic and combined. Diagnosis of arterial hypertension cannot be established on the basis of a single measurement, but it is necessary to make measurements in different situations and environments. The study aimed to evaluate efficacy of fixed combination antihypertensives in patients with stage I and II hypertension after antihypertensive monotherapy failed to deliver results in reducing blood pressure. In this study, we analyzed data of 395 hypertension patients aged between 65-80 years, previously treated with monotherapy. During 4 months of examination, 3 doctor visits were scheduled when their TA values were measured, and each of them received fixed-dose combination antihypertensives. The data obtained were processed by appropriate statistical analyzes.

At the third doctor visit, $69.8 \%$ patients achieved blood pressure target value, and the blood pressure decreased by $16.6 / 12.3 \%(p=0.000)$. The noninvasive $24 \mathrm{~h}$ Holter monitoring showed significantly less oscillation in blood pressure values throughout the day, and also, much smaller percentage of patients forgot to take therapy. During this study, the efficiency of fixed-dose combination antihypertensives was proved considering that in a considerable number of patients blood pressure reached the target values, there were no unwanted side effects, the patients rarely forgot to take the medicine, and there were significantly less oscillation in blood pressure on Holter monitoring.
\end{abstract}

Acta Medica Medianae 2021;60(1):79-84.

Key words: arterial hypertension, fixed combination antihypertensives, antihypertensive monotherapy

\footnotetext{
${ }^{1}$ Dr Nikolić Policlinic, Niš, Serbia

${ }^{2}$ Clinic of Pulmonary Disease, Clinical Center Niš, Niš, Serbia ${ }^{3}$ Clinic of Anesthesiology and Intensive therapy, Clinical Center Niš, Niš, Serbia

${ }^{4}$ University of Niš, Faculty of Medicine, Niš, Serbia

${ }^{5}$ Pediatric Internal Disease Clinic, Clinical Center, Niš, Serbia

${ }^{6}$ Clinic of Cardiovascular Diseases, Clinical Center Niš, Niš,

Serbia

7 University of Niš, Department of Cardiac Surgery, Faculty of Medicine, Niš, Serbia

${ }^{8}$ University of Salzburg, Department of Biosciences, Salzburg, Austria
}

Contact: Nemanja Nikolić

3/11 Vojvode Tankosića St., 18000 Niš, Serbia

E-mail: nemanja.nikolic23@gmail.com

\section{Introduction}

Arterial hypertension (high blood pressure) is the condition where one or both components of the blood pressure are elevated. The normal value for systolic blood pressure is $<140 \mathrm{~mm} \mathrm{Hg}$ and for diastolic < $90 \mathrm{~mm} \mathrm{Hg}(3,5)$.

Arterial hypertension with its complications (ischemic heart disease, cardiomyopathies, cerebrovascular disease) is the leading factor of cardiovascular mortality (1).

The condition where the systolic blood pressure is $\geq 140 \mathrm{~mm} \mathrm{Hg}$ and diastolic $\leq 90 \mathrm{~mm} \mathrm{Hg}$, is defined as isolated systolic hypertension. The values of systolic blood pressure $\leq 140 \mathrm{~mm} \mathrm{Hg}$ and $\geq 90$ $\mathrm{mm} \mathrm{Hg}$ for diastolic blood pressure are common for isolated diastolic hypertension.

To diagnose arterial hypertension, several measurements are necessary. It is not recommended to confirm diagnosis based on one measurement, particularly not the one measured in the ambulance. The measurements should be done at 
different times and different environment (home, office, ambulance) (1-4).

The treatment has as a goal to lower the blood pressure to $<140 / 90 \mathrm{~mm} \mathrm{Hg}$ in all patients. If the treatment is well tolerated, the values should go bellow $130 / 80 \mathrm{~mm} \mathrm{Hg}$ in most patients. In patients younger than 65 it is recommended to lower systolic blood pressure to the range $120-129 \mathrm{~mm} \mathrm{Hg}$ in most cases. In older patients ( $\geq 65-80$ years old), it is recommended to keep the systolic blood pressure between 130 to $139 \mathrm{~mm} \mathrm{Hg}$. A target diastolic blood pressure at or below $80 \mathrm{~mm} \mathrm{Hg}$ should be considered for all hypertensive patients, regardless of the degree of risk or comorbidity (3).

Fixed combination is recommended as an initial treatment of arterial hypertension with the exception of old vulnerable persons and persons with low risk persons and stage one hypertension (3).

\section{The aim}

The study aimed to evaluate efficacy and safety of antihypertensive drugs in the fixed combination (ACE inhibitors/Ca-antagonist) in patients with stage I and II hypertension after the monotherapy failed to deliver results in reducing blood pressure.

\section{Materials and methods}

\section{Patients}

Patients between 65-80 years old with stage I and II hypertension were included in the study after the monotherapy (beta blockers, calcium channel blockers, diuretics, etc.) failed to deliver results. According the newest ESH/ECS guidelines, target blood pressure in hypertensive patients between 6085 years old is $130-139 / 80 \mathrm{~mm} \mathrm{Hg}$.

The exclusion criteria were: not signed informed consent, non-compliance, hypersensitivity to calcium channel blockers and ACE inhibitors, pregnancy, neoplastic diseases with short life expectancy, severe heart defect, abnormalities in biochemical values that are clinically relevant, especially hyperkalemia.

\section{Blood pressure measurement and biochemical assays}

During four months, patients had three visits to a medical doctor ( 1 day = visit 1 , the first month $=$ visit 2 , and the fourth month = visit 3). The blood pressure was measured twice at every visit in the range of $3 \mathrm{~min}$. To every patient, one of four combinations of the fixed dose was prescribed $(5 / 5 \mathrm{mg}$, $5 / 10 \mathrm{mg}, 10 / 5 \mathrm{mg}$ or $10 / 10 \mathrm{mg}$ ) by the medical doctor, based on the blood pressure values with the possibility of drug dose titration.

Furthermore, the biochemical assays were also performed during each visit: blood count, liver and kidney function tests, electrolytes values, blood glucose, serum cholesterol, uric acid, creatinine kinase.

\section{Statistical analysis}

The values are presented as mean \pm standard deviation for continuous variables and numbers (percentages) for categorical variables. The data were analysed by descriptive statistics (mean and standard deviation) and by comparative parametric (t-test) and non-parametric (Fischer test) tests using GraphPad Prism 5.03 (San Diego, USA); p < 0.05 was considered as statistically significant.

\section{Results}

Three hundred and ninety-five patients of average age $72.2 \pm 7.0$ were involved in the study (Table 1). Of them, 289 (73.16\%) were males and $106(26.84 \%)$ were females. The average body mass index (BMI) was $31.6 \pm 4.9 \mathrm{~kg} / \mathrm{m}^{2}$. Before the study was started, the average blood pressure was 157.5/91.3 \pm 9.6/7.6 mm $\mathrm{Hg}$. Hypertension was present in patients of average age $13.2 \pm 7.9$ years. One hundred and forty-six patients (36.96\%) were diagnosed with stage I hypertension and 249 $(63.03 \%)$ with stage II hypertension. Cardiovascular risk factors were notices in 308 (77.97\%) patients. Dyslipidemia was the most common risk factor for cardiovascular complications in 333 (84.4\%) patients. Other risk factors, as obesity (BMI $\geq 30$ $\mathrm{kg} / \mathrm{m}^{2}$ ) was noticed in $181(45.9 \%)$ patients, smoking in 92 (23.4\%), family anamnesis (early acute myocardial infarction) in 86 (21.7\%) and hyperuricemia in $83(21.1 \%)$ patients. The target organ lesions were detected in 192 (48.7\%) patients, left ventricular hypertrophy in 128 (32.5\%), elevated values of serum creatinine in $22(5.6 \%)$ and microalbuminuria in 36 (9.2\%) patients.

The effects of fixed dose ACE inhibitors/Caantagonists combination

The treatment was successful in 276 (69.8\%) patients after four months (visit 3). Based on the blood pressure values, the recommended fixed dose of ACE inhibitors/Ca-antagonists was proposed by cardiologists (Table 2).

The blood pressure was significantly reduced (16.6/12.3\%) from 157.5/91.3 $\pm 9.6 / 7.6 \mathrm{~mm} \mathrm{Hg}$ at visit 1 to $130.9 / 79.6 \pm 7.4 / 5.9 \mathrm{~mm} \mathrm{Hg}$ at visit 3 $(p=0.000)$. During the $2^{\text {nd }}$ and $3^{\text {rd }}$ visit, in $32.3 \%$ and $69.8 \%$ of patients the blood pressure was reduced, respectively. The level of blood pressure reduction depended on the fixed dose used during the treatment. After four months of treatment, at the $3^{\text {rd }}$ visit, targeted blood pressure values were achieved in $24.1 \%$ of patients taking $10 / 10 \mathrm{mg}, 21.8 \%$ of patients taking $5 / 5 \mathrm{mg}, 20.5 \%$ taking $10 / 5 \mathrm{mg}$, and $1.8 \%$ of patients who were treated with $5 / 10 \mathrm{mg}$ (Table 3). The reduced blood pressure was followed with the changes in the heart rate. Heart rate significantly decreased $(5.1 \pm 7.5 / \mathrm{min}, \mathrm{p}=0.000)$ 
from $78.0 \pm 8.5 / \mathrm{min}$ at visit 1 to $72.9 \pm 6.0 / \mathrm{min}$ at visit 3.

The second aim of the study was to evaluate the efficacy and safety and the effects on the metabolism of the fixed dose of ACE inhibitors and Ca-antagonists. Considering lipid profile, total cholesterol was reduced from $5.50 \pm 1.13 \mathrm{mmol} / \mathrm{L}$ at visit 1 to $5.20 \pm 0.95 \mathrm{mmol} / \mathrm{L}$ at visit 3 ( $p=0.000)$, LDL cholesterol from $3.20 \pm 0.93 \mathrm{mmol} / \mathrm{L}$ at visit 1 to $3.00 \pm 0.77 \mathrm{mmol} / \mathrm{L}$ at visit $3(p=0.000)$, triglycerides were reduced from $2.20 \pm 1.14 \mathrm{mmol} / \mathrm{L}$ at visit 1 to $2.00 \pm 1.97 \mathrm{mmol} / \mathrm{L}$ at visit $3(\mathrm{p}=$ 0.000 ), while the levels of HDL cholesterol increased from $1.30 \pm 0.42 \mathrm{mmol} / \mathrm{L}$ at visit 1 to $1.35 \pm 0.30$ $\mathrm{mmol} / \mathrm{L}$ at visit $3(\mathrm{p}=0.001)$. There were no changes in the other biochemical parameters. The fixed doses of ACE inhibitors/Ca-antagonists were well tolerated and no adverse effects were reported.

Table 1. Patients previously on antihypertensive monotherapy $(n=395)$

\begin{tabular}{|l||c||}
\hline \multicolumn{1}{|c||}{ Drugs } & (\%) \\
\hline \hline Beta-blockers & $23(5.9)$ \\
\hline Diuretics & $41(10.3)$ \\
\hline ACE inhibitors & $193(48.9)$ \\
\hline Ca-antagonists & $138(34.9)$ \\
\hline
\end{tabular}

Table 2. Subsequent dosing of ACEI/Ca antagonists in a fixed dose within each visit $(n=395), n(\%)$

\begin{tabular}{||l||c|c|c||}
\hline $\begin{array}{c}\text { Doses of ACEI/Ca-antagonists } \\
\text { fixed combination }\end{array}$ & Visit 1 & Visit 2 & Visit 3 \\
\hline $5 / 5 \mathrm{mg}$ & $155(39.3)$ & $115(29.2)$ & $111(28.1)$ \\
\hline $5 / 10 \mathrm{mg}$ & $22(5.6)$ & $21(5.3)$ & $21(5.2)$ \\
\hline $10 / 5 \mathrm{mg}$ & $105(26.5)$ & $118(29.9)$ & $116(29.3)$ \\
\hline $10 / 10 \mathrm{mg}$ & $113(28.5)$ & $141(35.7)$ & $148(37.5)$ \\
\hline
\end{tabular}

Table 3. Doses of fixed combination of ACEI/Ca antagonists in patients reached the target blood pressure values at visits 2 and $3(n=395), n(\%)$

\begin{tabular}{||l||c|c|c||}
\hline \multicolumn{1}{|c||}{ Drugs Dose } & Visit 2 & Visit 3 & $\boldsymbol{p}$ \\
\cline { 2 - 4 } & $126(32.3)$ & $276(69.8)$ & 0.000 \\
\hline \hline $5 / 5 \mathrm{mg}$ & $47(11.8)$ & $86(21.8)$ & 0.000 \\
\hline $5 / 10 \mathrm{mg}$ & $7(1.8)$ & $13(3.4)$ & 0.000 \\
\hline $10 / 5 \mathrm{mg}$ & $37(9.4)$ & $81(20.5)$ & 0.000 \\
\hline $10 / 10 \mathrm{mg}$ & $37(9.3)$ & $95(24.1)$ & 0.000 \\
\hline
\end{tabular}

The noninvasive Holter monitoring was used for 24h (Schiller BR-102 plus system) in 176 (44\%) patients. The system was programed to measure the blood pressure at every $15 \mathrm{~min}$ from 07 am to $11 \mathrm{pm}$, and at every $20 \mathrm{~min}$ from $11 \mathrm{pm}$ to $07 \mathrm{am}$. The patients were practicing a normal daily routine. This monitoring revealed that patients treated with the antihypertensive in fixed dose had statistically significant reduction in the blood pressure oscillation during $24 \mathrm{~h}$ (Graph 1). The blood pressure was in the range $130.4 / 78.7 \pm 6.5 / 3.8 \mathrm{~mm} \mathrm{Hg}$. However, the blood pressure significantly oscillated during $24 \mathrm{~h}$ in patients treated with monotherapy, i.e., the values were 143.9/89.7 \pm 9.8/7.6 $\mathrm{mm} \mathrm{Hg}$.

The patients involved in the study have been checking the blood pressure on their own. It was noticed that patients treated with fixed dose were taking the therapy more regularly (96.5\%) than patients treated with monotherapy. The patients on combined monotherapy mostly forgot evening dose of the drug $(26.6 \%)$. 


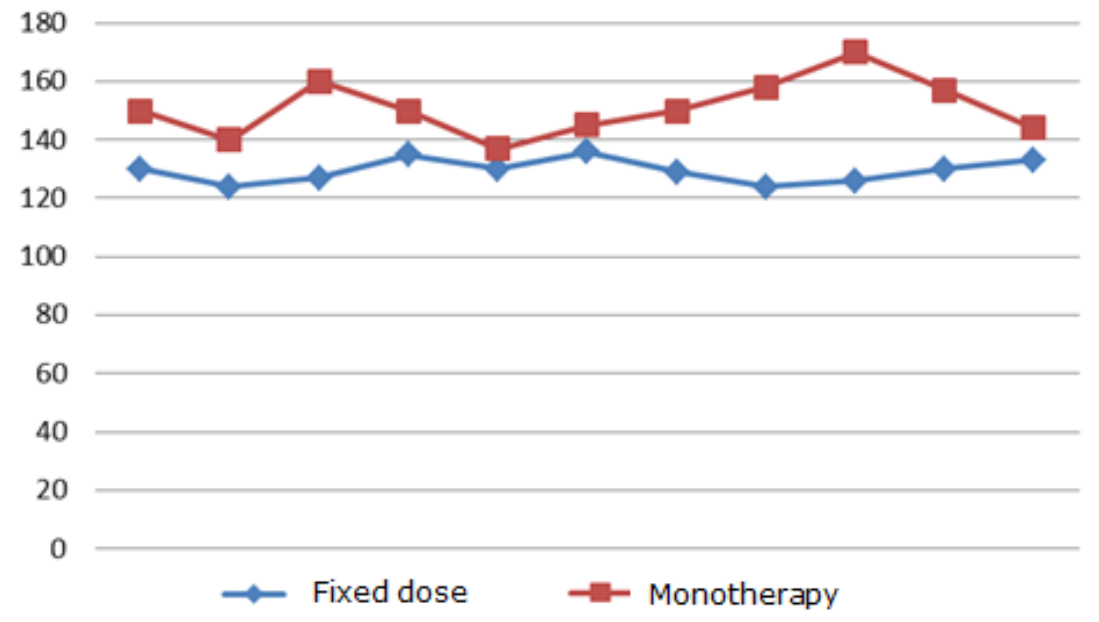

Graph 1. Blood pressure oscillations during ingestion of fixed dose/monotherapy detected with $24 \mathrm{~h}$ Holter

\section{Discussion}

In this clinical study, it has been shown that the combination of fixed dose of ACE inhibitors/Caantagonists significantly reduced blood pressure in patients with high risk factor for cardiovascular diseases. In patients in whom previous mono-antihypertensive therapy had failed to achieve target blood pressure (130-139/80 $\mathrm{mm} \mathrm{Hg}$ ), the treatment was continued with combined fixed dose of ACE inhibitors/Ca-antagonists. This approach led to a moderate decrease in the blood pressure values $(26.6 / 11.7 \mathrm{~mm} \mathrm{Hg})$ and the rate of achieving the target level of blood pressure was $69.8 \%$. In these patients, the lower level of blood pressure was noticed already after one month of treatment with the fixed dose of ACE inhibitors/Ca-antagonists (10).

Our data suggest that this approach can have long-lasting benefits in later cardiovascular events. The rate of achieving the target level of blood pressure could be even higher with a higher dose of combined fixed dose therapy (10/10 mg) because until last visit only $37.5 \%$ of patients took this dose of the drug. Furthermore, the metabolic effect of this therapy approach was significant in patients with dyslipidemia. The lipid profile was improved after four months of treatment. During the treatment, no adverse effects were noticed.

It has been shown that a fixed combination of antihypertensive drugs significantly lower oscillation in blood pressure during $24 \mathrm{~h}$ compared to the monotherapy approach. Moreover, this study showed that patients using this treatment approach forget less to take the therapy, what significantly increases the comfort for the patient.

The randomized, prospective, 18 weeks lasting double-blind study was carried out in Brazil with an aim to compare the efficacy and tolerability of the fixed dose of amlodipine/ramipril $(8,11)$. The patients involved in the study with basic hypertension type I and II. They were taking $2.5 / 2.5 \mathrm{mg}$ ra- mipril/amlodipine or $5 \mathrm{mg}$ amlodipine. Thereafter, the doses were titrated based on blood pressure, ramipril/amlodipine $5 / 5 \mathrm{mg}$, then $10 / 10 \mathrm{mg}$ or amlodipine $5 \mathrm{mg}$, and then $10 \mathrm{mg}$. This study proved that fixed combined therapy ramipril/amlodipine significantly reduced average changing of blood pressure during $24 \mathrm{~h}$, compared to the patients using the monotherapy approach.

Recent ESC/ESH guidelines emphasized the importance of RAAS activity inhibition in the treatment of primary hypertension $(5,6)$. The inhibition of RAAS activity could be achieved with ACE inhibitors or angiotensin receptor blockers (ARB). A recent meta-analysis revealed that the treatment with ACE inhibitors decreased all-cause mortality, mortality from cerebrovascular events, whereas ARB didn't show these effects. Therefore, ACE inhibitors are considered as the first-line therapy to avoid the increase in mortality and morbidity in this population. ACE inhibitors in the combination with Ca-antagonists have a synergistic antihypertensive effect, what can have an additional advantage in minimizing adverse effects of individual components (e.g., Edema with dihydropyridine CCBs). AngloScandinavian cardiac outcome trials for reducing the blood pressure showed that ACE inhibitors/Ca-antagonists combination was more effective in reducing blood pressure and also decreased the risk of mortality and major cerebrovascular events, compared to the traditional combination of beta-blockers and thiazide $(7,9,13)$.

\section{Conclusion}

In patients with stage I and II hypertension and with a high risk of cerebrovascular events when the previous treatment with the usage of a single antihypertensive drug failed to deliver results, the combination of the fixed does of ACE inhibitors/Caantagonists therapy approach was effective. Furthermore, this combination of drugs was well tolerable 
with good metabolic effects. It has been shown that this fixed combination prevents huge oscillation in blood pressure during $24 \mathrm{~h}$, compared to mono- therapy. Patients did not forget to take therapy on time, compared to the patients who were taking combined monotherapy.
1. Lenfant C. Reflections on hypertension control rates: a message from the director of the National Heart, Lung, and Blood Institute. Arch Intern Med. 2002 Jan 28;162(2):131-2. [CrossRef] [PubMed]

2. Burt VL, Cutler JA, Higgins M, Horan MJ, Labarthe D, Whelton $\mathrm{P}$, et al. Trends in the prevalence, awareness, treatment, and control of hypertension in the adult US population: data from the health examination surveys, 1960 to 1991 . Hypertension 1995;26(1):60-9. [CrossRef] [PubMed]

3. Williams B, Mancia G, Spiering W, Agabiti Rosei E, Azizi M, Burnier M, et al. 2018 ESC/ESH guidelines for the management of arterial hypertension. Eur Heart J. 2018 Sep 1;39(33):3021-104. [CrossRef] [PubMed]

4. Ilic S, Deljanin-Ilic M. Tretman arterijske hipertenzije. Acta Facultatis Medicinae Naissensis 2004;21(1):5963.

5. Mancia G, De Backer G, Dominiczak A, Cifkova R, Fagard R, Germano G, et al. 2007 guidelines for the management of arterial hypertension: The task force for the management of arterial hypertension of the European Society of Hypertension (ESH) and of the European Society of Cardiology (ESC). J Hypertens 2007;25:1105-87. [CrossRef] [PubMed]

6. Mancia G, Fagard R, Narkiewicz K, Redón J, Zanchetti A, Böhm M, et al. 2013 ESH/ESC guidelines for the management of arterial hypertension: The task force for the management of arterial hypertension of the European Society of Hypertension (ESH) and of the European Society of Cardiology (ESC). J Hypertens 2013;31:1281-357. [CrossRef] [PubMed]

7. Heart Outcomes Prevention Evaluation Study Investigators. Effects of ramipril on cardiovascular and microvascular outcomes in people with diabetes mellitus: Results of the HOPE study and MICRO-HOPE substudy. Lancet 2000;355(9200):253-9. [CrossRef] [PubMed]
8. Weir MR. Targeting mechanisms of hypertensive vascular disease with dual calcium channel and reninangiotensin system blockade. J Hum Hypertens 2007; 21(10):770-9 [CrossRef] [PubMed]

9. Tomcsányi J. Monitoring of the blood pressure lowering effectiveness of ramipril-amlodipine fix combination - A non-interventional trial (RAMONA study) (Hungarian). Hypertonia es Nephrologia 2013;17:34-8

10. Kikuya M, Hozawa A, Ohokubo T, Tsuji I, Michimata $M$, Matsubara $M$, et al. Prognostic significance of blood pressure and heart rate variabilities: The Ohasama study. Hypertension 2000 Nov;36(5):901-6.

[CrossRef] [PubMed]

11. Miranda RD, Mion D Jr, Rocha JC, Kohlmann O Jr, Gomes MA, Saraiva JF, et al. An 18-week, prospective, randomized, double-blind, multicenter study of amlodipine/ramipril combination versus amlodipine monotherapy in the treatment of hypertension: The assessment of combination therapy of amlodipine/ ramipril (ATAR) study. Clin Ther 2008;30(9):1618-28. [CrossRef] [PubMed]

12. Cheng J, Zhang W, Zhang X, Han F, Li X, He X, et al. Effect of angiotensin-converting enzyme inhibitors and angiotensin II receptor blockers on all-cause mortality, cardiovascular deaths, and cardiovascular events in patients with diabetes mellitus: A meta-analysis. JAMA Intern Med 2014;174(5):773-85 [CrossRef] [PubMed]

13. Dahlöf B, Sever PS, Poulter NR, Wedel H, Beevers DG, Caulfield $\mathrm{M}$, et al. Prevention of cardiovascular events with an antihypertensive regimen of amlodipine adding perindopril as required versus atenolol adding bendroflumethiazide as required, in the anglo-scandinavian cardiac outcomes trial-blood pressure lowering arm (ASCOT-BPLA): A multicentre randomised controlled trial. Lancet 2005;366(9489):895-906. [CrossRef] [PubMed] 


\title{
Originalni rad
}

UDC: 616.12-008.331.1:615.225

doi:10.5633/amm.2021.0111

\section{ISPITIVANJE EFIKASNOSTI FIKSNE KOMBINACIJE ANTIHIPERTENZIVA KOD BOLESNIKA KOJI SU BILI NA ANTIHIPERTENZIVNOJ MONOTERAPIJI}

\author{
Nemanja Nikolić1, Tomislav Kostić4,6, Marija Marinković2 , Mlađan Golubovićc,7, \\ Tamara Stojanović4 ${ }^{4}$ Milena Manojlovićs, Igor Petković ${ }^{8}$
}

${ }^{1}$ Poliklinika "Dr Nikolić", Niš, Srbija
${ }^{2}$ Klinika za plućne bolesti, Klinički centar Niš,
${ }^{3}$ Klinika za anesteziologiju i intenzivnu terap
${ }^{4}$ Univerzitet u Nišu, Medicinski fakultet, Niš,
${ }^{5}$ Klinika za dečije interne bolesti, Klinički ce
${ }^{6}$ Klinika za kardiovaskularne bolesti, Klinički
${ }^{7}$ Univerzitet u Nišu, Medicinski fakultet, Kat
${ }^{8}$ Univerzitet u Salzburgu, Medicinski fakultet,
Kontakt: Nemanja Nikolić
Vojvode Tankosića 3/11, 18000 Niš, Srbija
E-mail: nemanja.nikolic23@gmail.com

Arterijska hipertenzija je stanje u kome je krvni pritisak povišen iznad 140/90 mmHg. Ovo stanje, zajedno sa komplikacijama koje izaziva, vodeći je faktor kardiovaskularnog mortaliteta. Arterijska hipertenzija može biti sistolna, dijastolna i kombinovana. Dijagnoza arterijske hipertenzije ne može se postaviti samo na osnovu jednog merenja, već je neophodno izvršiti merenja u različitim situacijama i različitom okruženju. Cilj ove studije je da nadgleda efikasnost fiksne kombinacije antihipertenziva kod bolesnika sa hipertenzijom prvog ili drugog stepena, kod kojih se antihipertenzivnom monoterapijom nisu postigle adekvatne vrednosti krvnog pritiska. U ovom istraživanju analizirali smo podatke 395 bolesnika, starosti između 65 i 80 godina, koji boluju od hipertenzije prvog i drugog stepena i koji pomoću monoterapije nisu dostigli adekvatnu vrednost krvnog pritiska. Tokom 4 meseca ispitivanja, bolesnici su dolazili na kontrole u 3 navrata, pri čemu su im merene vrednosti krvnog pritiska i svaki od njih je primio kombinaciju fiksne doze antihipertenziva. Dobijeni podaci obrađeni su odgovarajućim statističkim analizama. Prilikom treće posete lekaru, ciljnu vrednost krvnog pritiska dostiglo je $69,8 \%$ bolesnika, a pritisak se smanjio za 16,6 , odnoso za $12,3 \%$ ( $p=$ $0,000)$. Neinvazivni dvadesetčetvoročasovni holter monitoring pokazao je znatno manje oscilacije u vrednostima krvnog pritiska u toku dana, a takođe, bolesnici su u mnogo manjem procentu zaboravljali da uzimaju terapiju. Tokom ove studije dokazana je efikasnost fiksne doze antihipertenziva, s obzirom na to da je kod znatnog broja bolesnika krvni pritisak doveden na ciljne vrednosti, da nije bilo neželjenih efekata, da su bolesnici ređe zaboravljali da uzimaju lek i da su na holter monitoringu zabeležene znatno manje oscilacije krvnog pritiska.

Acta Medica Medianae 2021;60(1):79-84.

Ključne reči: arterijska hipertenzija, fiksna kombinacija antihipertenziva, antihipertenzivna monoterapija 